\title{
The life table paradox: has Brazil already overcome it?
}

\author{
Filipe Costa de Souza*
}

Ideally, life expectancy should be a decreasing function of age. When this fact is not observed, this situation is known as the life table paradox. This paper investigated the timing (and health metrics at the time) in which Brazil and its Federation Units (FU) overcame (or are expected to overcome) this paradox. The data were gathered from the Brazilian Institute of Geography and Statistics and contained 3,416 sex-specific abridged life tables, from 2000 to 2060 . At national level, females and males overcame the paradox in 2016 and 2018, respectively. However, when the FU were examined separately, much heterogeneity was observed. Through the decomposition analysis of the change over time in the difference between life expectancy at birth and at age one, we found that Brazil and most of its FU are expected to have both changes declining over time and the total change is expected to be decreasing and greater than zero. Nevertheless, for some Northeastern states the total change is expected to pass from a positive to a negative value; and for two Northern states the total change is expected to be neither decreasing nor increasing. In a public planning perspective, we understand that achieving balancing in the life tables is a goal to be pursued, especially because having an imbalanced table means that life expectancy at birth is still strongly influenced by high levels of infant mortality. Therefore, this knowledge could help planners to properly define strategies to accelerate the balancing process and revert unequal scenarios.

Keywords: Life tables. Life expectancy. Infant mortality. Health inequalities. Regional Inequalities. Decomposition.

\footnotetext{
* Universidade Federal de Pernambuco (UFPE), Recife-PE, Brazil (filipe.costas@ufpe.br; https://orcid.org/0000-00019903-5403).
} 


\section{Introduction}

Period life expectancy at birth and infant mortality are the two main social indicators of public health, development and wellbeing of a population (VAUPEL, 2010; SIMEONI; FROVA; DE CURTIS, 2019; GISBERT, 2020). Historically, reductions in child and infant mortality, especially due to reduction in infectious diseases (MATHERS et al., 2015), promoted major positive effects in increasing life expectancy at birth and in reducing the variation in length of life distribution (SMITS; MODEN, 2009).

Dubey, Ram and Ram (2015) affirm that, ideally, life expectancy should be a monotonically decreasing function of age, so its maximum could be attained at age zero. However, according to Canudas-Romo and Becker (2011) this characteristic only started to be observed in the most developed nations in the second half of the twentieth century, more precisely, in 1957, for Icelandic females.

Canudas-Romo and Becker (2011) define an imbalanced life table as a life table where the complete life expectancy at a given age $x$ is lower than the complete life expectancy in a given age $y$, with $x<y$. Traditionally, this imbalance is observed between life expectancy at birth and at age one, due to the high rates of infant mortality. According to Rowland (2003), this counterintuitive situation is known as the paradox of the life table, and it is still observed in populations in the middle (or earlier stages) of the demographic transition. Therefore, the world can be divided in countries/regions that have already overcome the paradox and those that have not (CANUDAS-ROMO; BECKER, 2011).

Although Brazil has achieved important improvements in health and socioeconomic development over the past decades (BOING et al., 2020), Borges (2017) adverts that life expectancy at birth is still greatly impacted by infant mortality (and, therefore, may provide a poor measure of lifespan), and it is still far from the level of most developed nations (ALVAREZ; ABURTO; CANUDAS-ROMO, 2020). Additionally, Brazil is one of the most unequal nations around the globe (BOING et al., 2020), and persistently marked by social and regional inequalities (BOCCOLINI; SOUZA JUNIOR, 2016).

The Brazilian Constitution, in Article 196, establishes health as a universal right and a responsibility of the State, which should guarantee equitable and universal access to healthcare. Therefore, regional and social inequalities in health conditions are unacceptable and should be continuously combated (SIMEONI; FROVA; DE CURTIS, 2019).

In this context, and inspired by the work of Canudas-Romo and Becker (2011), this article aims at investigating the timing (and health metrics at the moment) in which Brazilian Federation Units overcame (or are expected to overcome) the life table paradox, and at exploring regional and sex health inequalities. To that end, three main health metrics were used in this study: the period life expectancy at birth and at age one, and the infant mortality. In addition, to make this investigation possible, we used official sex-specific abridged life tables, from 2000 to 2060, for Brazil and each one of its 27 Federation Units. 
To understand the balancing process of each life table under study, and how it is expected to behave over time, we performed the Kitagawa's decomposition analysis. Moreover, to provide an idea of the estimated (and projected) magnitude of the health inequality for males and females in Brazil during the period under investigation, which also allows for a discussion about the convergence/divergence process in health indicators among the Federation Units, we also calculated the gaps between best- and worst-practices in life expectancy (OEPPEN; VAUPEL, 2002) at birth and in infant mortality.

Besides the importance of providing new points of view about longitudinal investigations of mortality, by discussing the time of the crossing between life expectancy at birth and at age one, and the role of infant mortality in this process; this investigation could provide relevant information for public planners, once having balanced life tables is a goal to be pursued. This becomes clear, especially for the regions still in the balancing process, because, as stated by Gisbert (2020), even though reductions in mortality levels in any age imply an increase in life expectancy at birth, when those improvements are caused by reduction in mortality at young ages (particularly at the first year of life), they also cause a reduction in the variability (inequality) of the length of life distribution. This type of inequality is sometimes viewed as the worst type of inequality a person could suffer, especially because it is impossible to transfer life time from a person to another, and because all other types of inequalities require the person to be alive (GISBERT, 2020).

\section{Material and methods}

Data

According to Shkolnikov (2017, p. 1), "life tables are the oldest and most important tool in demography", and their projections are also essential for social planning, providing, at least, a first impression of the mortalities trends to come (SOUZA, 2020). For the investigation, we used sex-specific life tables, from 2000 to 2060, for Brazil and each one of its 27 Federation Units, totalizing 3,416 abridged period life tables. The data were gathered freely, on June 16th, 2020, from the official website of the Brazilian Institute of Geography and Statistics - IBGE (https://www.ibge.gov.br/), and were based on the 2013 and the 2018 population projections of Brazil and its Federation Units (IBGE, 2013a, 2018a). The 2013 edition provided all the life tables from 2000 to 2009, while the 2018 edition provided the remaining official tables.

The 2013 edition of the population projection incorporated the results of the 2010 Population Census and the most recent information on the components (mortality, fertility and migration) of demographic growth. The mortality component remained the same in the 2018 projection (IBGE, 2018b). In the 2013 projection, three main datasets were consulted to construct the life tables: the Census, the Vital Statistics from IBGE, and the Mortality Information System from Brazilian Ministry of Health (IBGE, 2013b). After analyzing the 
number of deaths captured by each dataset and the expected mortality pattern for the Brazilian population, the data from the Mortality Information System were selected for the construction of the life tables (IBGE, 2013c).

To construct the projected life tables, for Brazil and each Federation Unit, a continuous reduction of the mortality levels was assumed, reaching the level of the most long-lived populations in 2100, according to the life tables provided by the U.S. Bureau of the Census Health (IBGE, 2013b). Additionally, to correct underreporting of deaths (above and below age one) direct and indirect demographic methods were used.

The resulting life tables were abridged for the ages of $0,1,5,10, \ldots, 85$ and 90 years and above and contained information such as: the number of persons alive at exact age $x, l_{x}$; the number of deaths between exact ages $x$ and $x+n,{ }_{n} d_{x}$; the age-specific death rate between exact ages $x$ and $x+n,{ }_{n} m_{x}$; the number of person-years lived between exact ages $x$ and $x+n$ (which could also be interpreted as the average number of persons alive between exact ages $x$ and $x+n),{ }_{n} L_{x}$; the complete period life expectancy at exact age $x$, $e_{x}$; among other life table metrics.

The 2013 and 2018 Brazilian population projections are fundamental to providing information for public and private planning. Readers interested in understanding how those projections were performed and learning details about the construction of the abridged life tables will benefit from the reading of IBGE (2013b, 2013c, 2018b).

\section{Methods}

Canudas-Romo and Becker (2011) proved that the crossover between $e_{0}$ and $e_{x}$ occur when $e_{0}=e_{x}=1 /{ }_{x} m_{0}$, and, in particular, since imbalanced life tables are typically characterized by the fact that $e_{0}<e_{1}$, then the age-specific death rate between exact ages 0 and $1,{ }_{1} m_{0}$, is a fundamental metric in studying the life table paradox. Following CanudasRomo and Becker (2011, p.118), we also refer to ${ }_{1} m_{0}$ as infant mortality (IM).

For Brazil and its 27 Federation Units, initially, it was verified (for males and females) the calendar year in which $e_{0}$ became (or is expected to become) strictly higher than $e_{1}$, and the values of $e_{0}, e_{1}$ and IM on that year. Those metrics allow for the comparison of the moment when each location overcame (or is expected to overcome) the life table paradox, and the analysis of important health indicators, which could help identify regional and sex inequalities (CANUDAS-ROMO; BECKER, 2011). Additionally, for each location, we also computed the gap between the year in which the female life table became (or is expected to become) balanced and the year in which the male life table became (or is expected to become) balanced. This gap (female minus male) was called Year Gap.

Following Canudas-Romo and Becker (2011) and Dubey, Ram and Ram (2015) we also performed Kitagawa's decomposition analysis to examine "the components of the change over time in the difference in life expectancies (at birth minus at age one)" (CANUDASROMO; BECKER, 2011, p. 120). In this perspective, let $t_{1}$ and $t_{2}$ be two calendar years, with $t_{2}>t_{1}$, and, for a given location, let $e_{x}\left(t_{i}\right)$ be the period life expectancy at age $x$ and 
at calendar year $t_{i}$, with the same logic being applied to ${ }_{1} L_{0}\left(t_{i}\right)$ and to ${ }_{1} d_{0}\left(t_{i}\right)$. Moreover, at any calendar year, $l_{0}$ is a constant equal to 100,000 (according to the value arbitrated in Brazilian official tables). So, the difference between $e_{0}$ and $e_{1}$ over time is decomposed as follows (CANUDAS-ROMO; BECKER, 2011; DUBEY; RAM; RAM, 2015):

$\left[e_{0}\left(t_{2}\right)-e_{1}\left(t_{2}\right)\right]-\left[e_{0}\left(t_{1}\right)-e_{1}\left(t_{1}\right)\right]=$

$\left\{\left[\frac{{ }_{1} L_{0}\left(t_{2}\right)-{ }_{1} L_{0}\left(t_{1}\right)}{l_{0}}\right]+\left[\frac{{ }_{1} d_{0}\left(t_{1}\right)-{ }_{1} d_{0}\left(t_{2}\right)}{l_{0}}\right] \cdot\left[\frac{e_{1}\left(t_{1}\right)+e_{1}\left(t_{2}\right)}{2}\right]\right\}+\left\{\left[\frac{e_{1}\left(t_{1}\right)-e_{1}\left(t_{2}\right)}{l_{0}}\right] \cdot\left[\frac{{ }_{1} d_{0}\left(t_{1}\right)+{ }_{1} d_{0}\left(t_{2}\right)}{2}\right]\right\}(1)$

According to the authors, the terms between the first pair of brackets on the right side of the equation represent the change occurring below age one (A), while the terms between the second pair represent the change above age one (B). In this study, we investigated the difference between $e_{0}$ and $e_{1}$ per decade, focusing on the trends of each component (A and $B)$ and how they impact the total change over time $(A+B)$.

Finally, to offer an idea of the magnitude of the health inequality experienced (and that is expected to be experienced) for males and females in Brazil over time, and to allow for a debate of the convergence/divergence process in health indicators (VALLIN; MESLÉ, 2004; MESLÉ; VALLIN, 2017) among Brazilian Federation Units, we also computed the male and female differences between the best- and worst-practice life expectancies (best minus worst), BW Gap; and between best- and worst-practice infant mortalities, IM Gap. Our definition of best -and worst- practices is based on Oeppen and Vaupel (2002) and, in this paper, for a given calendar year, the worst-practice life expectancy in Brazil is defined as the lowest life expectancy at birth among Brazilian Federation Units. The best-practice life expectancy, on the other hand, is the highest one. The worst-practice IM is the highest IM among Brazilian Federation Units, while the best-practice IM is the lowest one.

\section{Results}

According to the official life tables used in this article, at national level, females were the first to overcome the life table paradox in 2016, while for the males this happened two years later, in 2018. However, as it is well known, Brazil is a very unequal country and, evidently, this is also reflected in the timing in which each of its Federation Units overcame (or is expected to overcome) the paradox. Table 1 presents, for males and females and for Brazil and its Federation Units, a summary of the year when the life tables became (or are expected to become) balanced, i.e., the calendar year in which we start (or we are expected to start) to observe that $e_{0}$ is greater than $e_{1}$ and other health indicators at that moment.

The Federal District alongside with two Southern states (Santa Catarina and Rio Grande do Sul) were the first ones to have female balanced life tables in Brazil, in 2004. By 2006 and 2012 all states from the South and Southeast regions, respectively, had already overcome the life table paradox for the females. For males, the first state to overcome the paradox was also Rio Grande do Sul in 2006, followed by the Federal District and Santa Catarina in 
2007. Additionally, by 2013 , all states from the South and Southeast regions had already balanced their life tables.

On the other hand, until 2019, none of the states from the Midwest (with the exception of females from Mato Grosso do Sul) or from the North regions has already experienced the crossover between life expectancy at birth and at age one, which is also true for most of the Northeastern states, with the exception of Pernambuco and Ceará, for both males and females, and females from Rio Grande do Norte. Moreover, the state of Amapá has no value at Table 1 because until 2060 (the last year with official life table projections for each Federation Unit) the life expectancy at age one ( 81.57 for females and 76.07 for males) is still expected to be higher than the life expectancy at birth ( 81.28 for females and 75.81 for males). This fact also prevented us from calculating the expected gap in the timing of balancing between Federation Units. However, even without the precise expected timing of balancing for Amapá, we can compute the median calendar year of balancing for females and males, which are 2020 and 2022, respectively.

TABLE 1

Male and female year, $e_{0}$, IM, when the life tables became (or are expected to become) balanced, and the Year Gap

Brazil and Federation Units

\begin{tabular}{|c|c|c|c|c|c|c|c|}
\hline \multirow{2}{*}{ Location (acronyms) } & \multicolumn{3}{|c|}{ Male } & \multicolumn{3}{|c|}{ Female } & \multirow{2}{*}{$\begin{array}{l}\text { Year } \\
\text { Gap }\end{array}$} \\
\hline & Year & $e_{0}$ & IM & Year & $e_{0}$ & IM & \\
\hline Brazil (BR) & 2018 & 72.74 & 13.47 & 2016 & 79.31 & 12.32 & 2 \\
\hline \multicolumn{8}{|l|}{ North } \\
\hline Rondônia (RO) & 2045 & 72.62 & 13.65 & 2041 & 78.61 & 12.62 & 4 \\
\hline Acre $(A C)$ & 2029 & 73.71 & 13.42 & 2023 & 79.24 & 12.61 & 6 \\
\hline Amazonas (AM) & 2038 & 72.39 & 13.75 & 2025 & 77.53 & 12.66 & 13 \\
\hline Roraima (RR) & 2038 & 73.88 & 13.53 & 2049 & 79.98 & 12.46 & -11 \\
\hline Pará (PA) & 2029 & 70.24 & 14.01 & 2020 & 77.16 & 12.77 & 9 \\
\hline Amapá (AP) & - & - & - & - & - & - & - \\
\hline Tocantins (TO) & 2022 & 71.88 & 13.78 & 2025 & 78.71 & 12.47 & -3 \\
\hline \multicolumn{8}{|l|}{ Northeast } \\
\hline Maranhão (MA) & 2030 & 70.39 & 13.96 & 2028 & 77.37 & 12.68 & 2 \\
\hline Piauí (PI) & 2028 & 68.56 & 14.57 & 2031 & 78.15 & 12.68 & -3 \\
\hline Ceará (CE) & 2019 & 70.55 & 13.86 & 2018 & 78.26 & 12.34 & 1 \\
\hline Rio Grande do Norte (RN) & 2023 & 73.17 & 13.53 & 2016 & 79.77 & 12.46 & 7 \\
\hline Paraíba (PB) & 2020 & 70.47 & 13.82 & 2022 & 78.67 & 12.47 & -2 \\
\hline Pernambuco (PE) & 2016 & 69.92 & 14.20 & 2014 & 77.06 & 12.41 & 2 \\
\hline Alagoas (AL) & 2023 & 69.21 & 14.19 & 2025 & 79.09 & 12.64 & -2 \\
\hline Sergipe (SE) & 2021 & 69.65 & 14.18 & 2020 & 77.91 & 12.69 & 1 \\
\hline Bahia (BA) & 2023 & 70.43 & 14.10 & 2026 & 80.21 & 12.45 & -3 \\
\hline \multicolumn{8}{|l|}{ Southeast } \\
\hline Minas Gerais (MG) & 2013 & 73.46 & 13.50 & 2012 & 79.17 & 12.47 & 1 \\
\hline Espírito Santo (ES) & 2010 & 71.90 & 13.76 & 2008 & 79.32 & 11.85 & 2 \\
\hline Rio de Janeiro (RJ) & 2013 & 71.53 & 13.83 & 2011 & 78.23 & 12.64 & 2 \\
\hline São Paulo (SP) & 2009 & 72.14 & 13.66 & 2006 & 78.29 & 12.68 & 3 \\
\hline
\end{tabular}




\begin{tabular}{|c|c|c|c|c|c|c|c|}
\hline \multirow{2}{*}{ Location (acronyms) } & \multicolumn{3}{|c|}{ Male } & \multicolumn{3}{|c|}{ Female } & \multirow{2}{*}{$\begin{array}{l}\text { Yea } \\
\text { Gap }\end{array}$} \\
\hline & Year & $e_{0}$ & IM & Year & $e_{0}$ & IM & \\
\hline \multicolumn{8}{|l|}{ South } \\
\hline Paraná (PR) & 2010 & 71.87 & 13.47 & 2006 & 77.04 & 12.96 & 4 \\
\hline Santa Catarina (SC) & 2007 & 72.27 & 13.59 & 2004 & 77.74 & 12.66 & 3 \\
\hline Rio Grande do Sul (RS) & 2006 & 71.01 & 13.94 & 2004 & 77.62 & 12.61 & 2 \\
\hline \multicolumn{8}{|l|}{ Midwest } \\
\hline Mato Grosso do Sul (MS) & 2021 & 73.35 & 13.49 & 2017 & 79.47 & 12.51 & 4 \\
\hline Mato Grosso (MT) & 2032 & 74.42 & 13.32 & 2026 & 79.91 & 12.35 & 6 \\
\hline Goiás (GO) & 2022 & 71.96 & 13.83 & 2020 & 78.20 & 12.54 & 2 \\
\hline Federal District (DF) & 2007 & 71.45 & 13.98 & 2004 & 77.76 & 12.81 & 3 \\
\hline
\end{tabular}

Source: Author's calculations based on the Brazilian Institute of Geography and Statistics (https://www.ibge.gov.br/).

It is also interesting to highlight that in the year 2000, the crossing between life expectancy at birth and at age 5 had already occurred in all Federation Units but Alagoas. For this Northeastern state, this situation endured until 2000 for females, where $e_{0}=68.50$ and $e_{5}=68.60$, and until 2003 for males, where $e_{0}=61.67$ and $e_{5}=61.97$.

For all Federation Units but Amapá, the balancing of the life tables is expected to occur, for males, in the range of life expectancy at birth of 68.56 (in Piauí) and 74.42 (in Mato Grosso) and, for females, of 77.04 (in Paraná) and 80.21 (in Bahia). Moreover, those ranges tend to be higher since, in 2060 , as was pointed out, the male and female life expectancy at birth in Amapá are expected to be 75.81 and 81.28, respectively.

In turn, for all Federation Units but Amapá, the level of infant mortality is expected to vary from 13.32 (in Mato Grosso) to 14.57 (in Piauî) deaths per thousand live births, for males, and from 11.85 (in Espírito Santo) to 12.96 (in Paraná), for females. For Amapá, in 2060, the projected infant mortality levels for males and females are 16.62 and 15.81 , respectively. Moreover, the correlations between life expectancy at birth and the IM at the timing of the balancing is negative (and statistically significant, p-value $<0.05$ ) for both males (-0.93) and females (-0.55).

It is also worth noticing that, for Brazil and all its Federation Units that overcame (or are expected to overcome) the life table paradox by 2060 , females had higher life expectancies at birth and lower infant mortality levels than males at the timing of balancing, regardless of who (males or females) achieved (or are expected to achieve) the balancing first. In fact, from 2000 to 2060, the highest male life expectancy at birth at the time of balancing is lower than 74.5 years, while the lowest female life expectancy at birth at the timing of balancing is higher than 77 years.

Figure 1 shows males and females scatterplots of the timing of balancing versus the life expectancy at birth at that time. In each plot, Brazil and its five macroregions are highlighted using different colors to make regional clusters easier to spot. From those plots we can clearly observe regional clusters, especially for males, reinforcing some results already discussed. 
FIGURE 1

Males and females scatterplots of the timing of balancing vs. the life expectancy at birth at that time Brazil and Federation Units - 2000-2050

Males
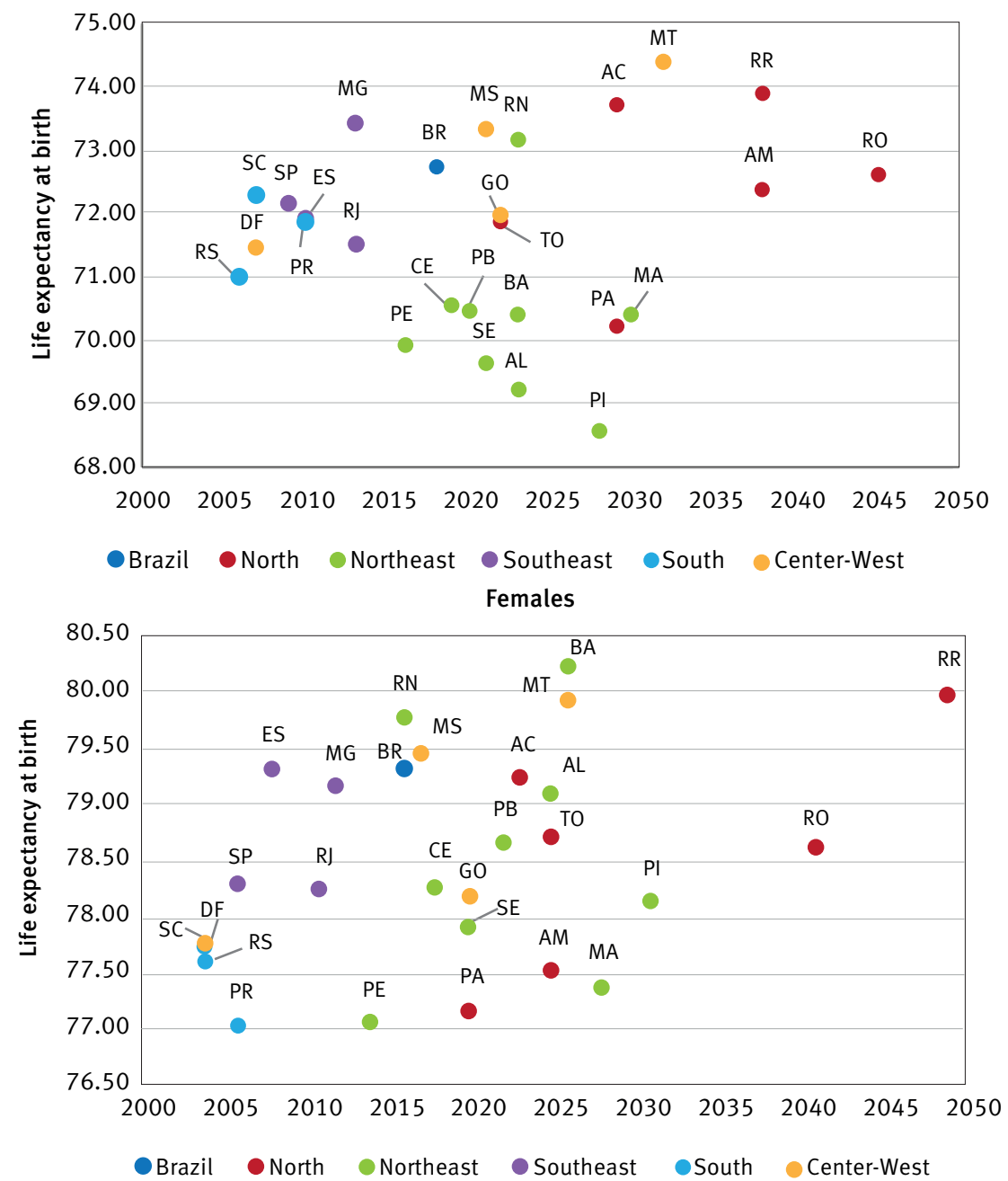

Source: Author's calculations based on the Brazilian Institute of Geography and Statistics (https://www.ibge.gov.br/).

Another point that deserves our attention is that in six states (Roraima and Tocantins, from the North, and Piauí, Paraíba, Alagoas and Bahia, from the Northeast), which still are in the process of balancing their life tables, male tables are expected to achieve balancing before the female ones. Moreover, the highest differences are observed in the North region. While in Amazonas females are expected to achieve balancing 13 years before males, in Roraima males are expected to overcome the paradox 11 years before females.

When we investigated the difference between $e_{0}$ and $e_{1}$ over time (per decade, from 2000 to 2060) and its components, by the decomposition analysis, it was possible to 
identify three main types of trends: $i)$ Both changes below age one (A) and changes above age one (B) decline over time and, for all periods under study, $|A|>|B|$ and $A+B$ (the total change over time) is decreasing and greater than zero; ii) Both $A$ and $B$ decline over time, but for the first periods $|A|>|B|$, and gradually this situation changes to $|B|>|A|$, so $A+B$ is decreasing and passes from a positive to a negative value; iii) Both changes $A$ and $B$ decline over time, and for all periods under study $|A|>|B|$, but $A+B$ is neither decreasing nor increasing, and might fluctuate over time or presents a bell shape. Moreover, for all periods under analysis, for both males and females and for Brazil and all its Federation Units, we have that $A>0$ and $B<0$. Examples of those types can be observed in Table 1 in the Appendix (Roraima (RR) - type iii; Pernambuco (PE) - type ii and São Paulo (SP), Rio Grande do Sul (RS), Distrito Federal (DF) and Brazil (BR) - type i).

In all datasets, Roraima and Amapá are the only two states of type iii. In both cases, for males, the total change fluctuates over time, while for females, the total change initially increases, reaching a maximum in 2020 and 2030, respectively, beginning to decline thereafter. The Northeastern states of Pernambuco, Rio Grande do Norte (for both males and females) and Alagoas and Ceará (for males) are the only locations of type ii. In Pernambuco, for example, for both males and females, the changes above age one are expected to have a greater impact at the total change than the changes below age one from 2040, as can be seen in Table 1 in the Appendix. Thus, after the crossing between $e_{0}$ and $e_{1}$ in the 2010s, the difference starts to increase, but in the late 2030s, for males, and early 2040s, for females, the difference between those values is expected to slowly reduce. Finally, Brazil and the rest of its Federation Units are expected to be of type $i$ and, after the crossing, the difference between $e_{0}$ and $e_{1}$ is expected to increase.

Our last analysis focused on the differences between the best- and worst-practices life expectancies at birth and between the best- and worst-practices infant mortalities. As stated, those metrics could provide an idea of the magnitude of the health inequalities experienced (and that are expected to be experienced) for males and females in Brazil over time, and also provide elements for the discussion about the convergence/divergence process of those health indicators among Brazilian Federation Units.

Figure 2 (a) shows, for males and females, the estimated and projected worst- and best-practices life expectancies at birth, from 2000 to 2060. For males, four Northeastern states had the worst results concerning life expectancy at birth (Pernambuco in 2000, Alagoas from 2001 to 2015, Maranhão in 2016 and Piauí from 2017 to 2060). On the other hand, Santa Catarina had the best-practice life expectancy at birth for all the period under analysis. For females, three states had the worst results (Alagoas from 2000 to 2002, Roraima from 2003 to 2025 and Rondônia from 2026 to 2060), and three Federation Units had the best results (Rio Grande do Sul from 2000 to 2001, Federal District from 2002 to 2004 and Santa Catarina from 2005 to 2060). Those findings help us highlight the health inequalities between the North and Northeast regions of Brazil and the South region. 
FIGURE 2

Best- and worst-practices life expectancies at birth (a), and the gap between them (b), for males and females

Brazil - 2000-2060

(a)

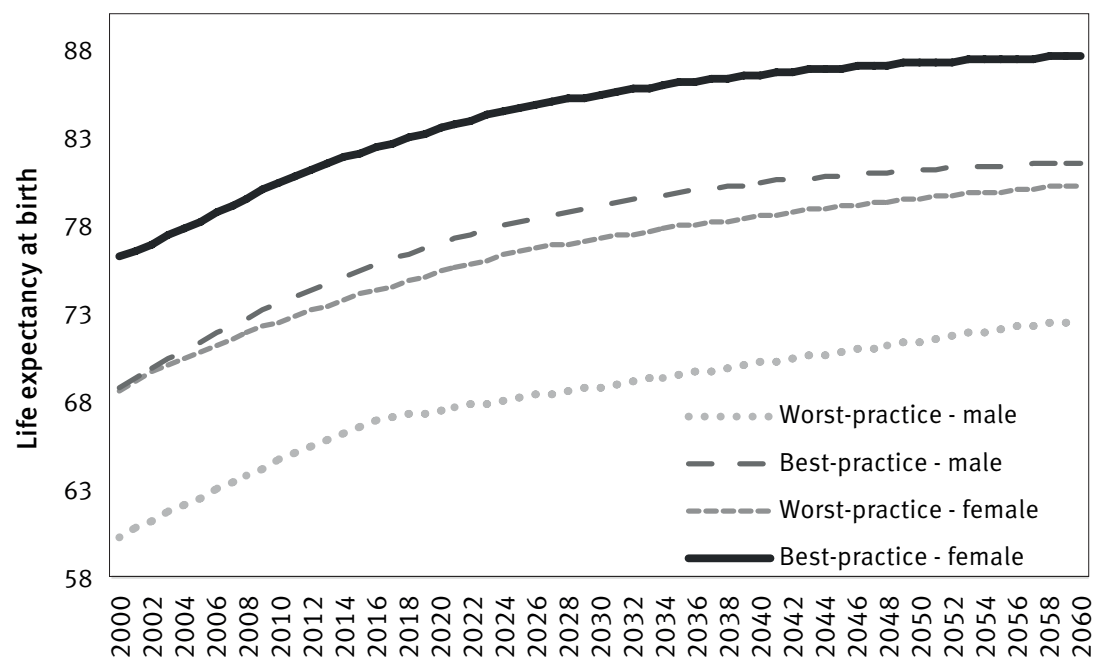

(b)

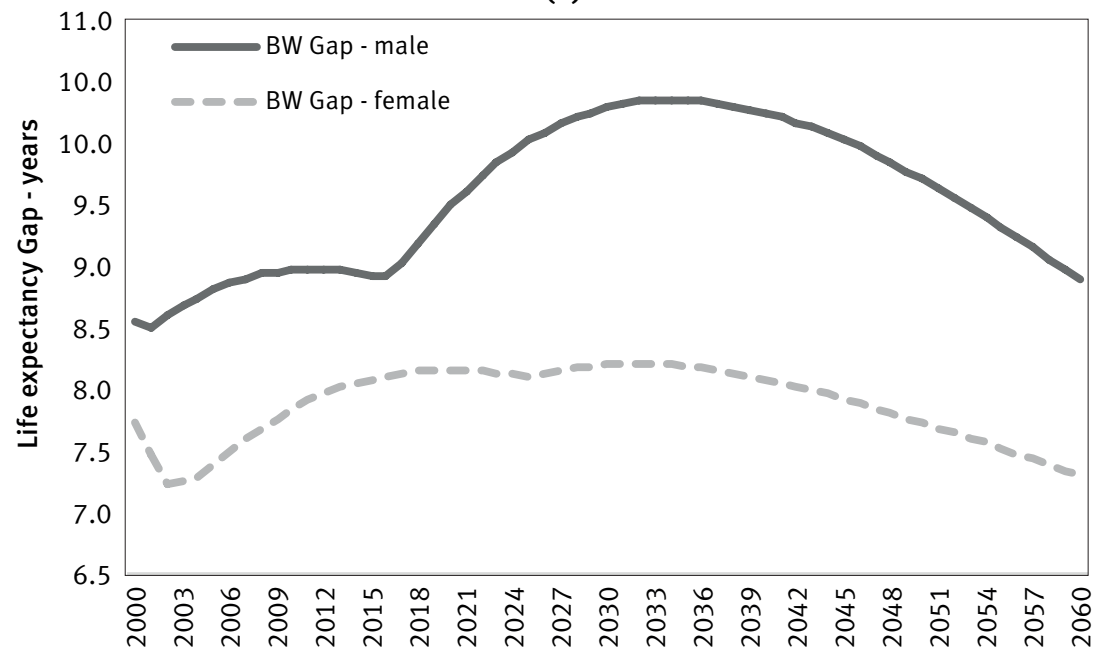

Source: Author's calculations based on the Brazilian Institute of Geography and Statistics (https://www.ibge.gov.br/). 
In addition, by Figure 2 (b), we can observe cycles of convergence and divergence between the best- and the worst-practice life expectancies at birth, for both males and females. For males, at those processes of convergence and divergence, the gap (BW Gap) achieved its lowest value in 2001 ( 8.50 years) and is expected to achieve its highest value in 2034 (10.35 years). For females, the gap achieved its lowest value in 2002 (7.32 years) and is expected to achieve its highest value in 2032 ( 8.20 years), which indicates a higher inequality among males.

Figure 3 (a) shows, for males and females, the estimated and projected worst- and best-practices in infant mortality, from 2000 to 2060. For both males and females, the worst-practices in infant mortality had great improvements from the 2000 s to the early 2010s, going, respectively, from 79.79 and 53.86 deaths per thousand live births in 2000 to 25.05 and 23.52 in 2015 , which caused a great reduction in the gaps between bestand worst-practices in infant mortality (IM GAP), as can be seen in Figure 3 (b). For males, the reduction in the gap is expected to last until 2020, but from 2021 to 2031 the gap is expected to have a small rise, returning to decrease from 2032. For females, the reduction in the gap lasted until 2013, and from 2014 to 2020 the gap is expected to have a small rise, returning to decrease from 2021.

For males, three states had the worst results concerning infant mortality (Alagoas from 2000 to 2010, Maranhão from 2011 to 2015, and Amapá from 2016 to 2060), and for females, two states had the worst results (Alagoas from 2000 to 2012, and Amapá from 2013 to 2060). Those bad indicators from Amapá help explain why it is expected to be the last state to overcome the life table paradox. On the other hand, for males, the Federal District and the states from the South had (and are expected to have) the best-practices (Federal District from 2000 to 2002, Rio Grande do Sul from 2003 to 2007, Santa Catarina from 2008 to 2020, and Paraná from 2021 to 2060), while for females, Espírito Santo joins those four Federation Units (Federal District in 2000, Rio Grande do Sul from 2001 to 2004 , Santa Catarina from 2005 to 2009, Espírito Santo from 2010 to 2030 and Paraná from 2031 to 2060). Once again, those findings helped emphasize the regional inequalities in health in Brazil. 
FIGURE 3

Best- and worst-practices in infant mortality (a), and the gap between them (b), for males and females Brazil - 2000-2060

(a)

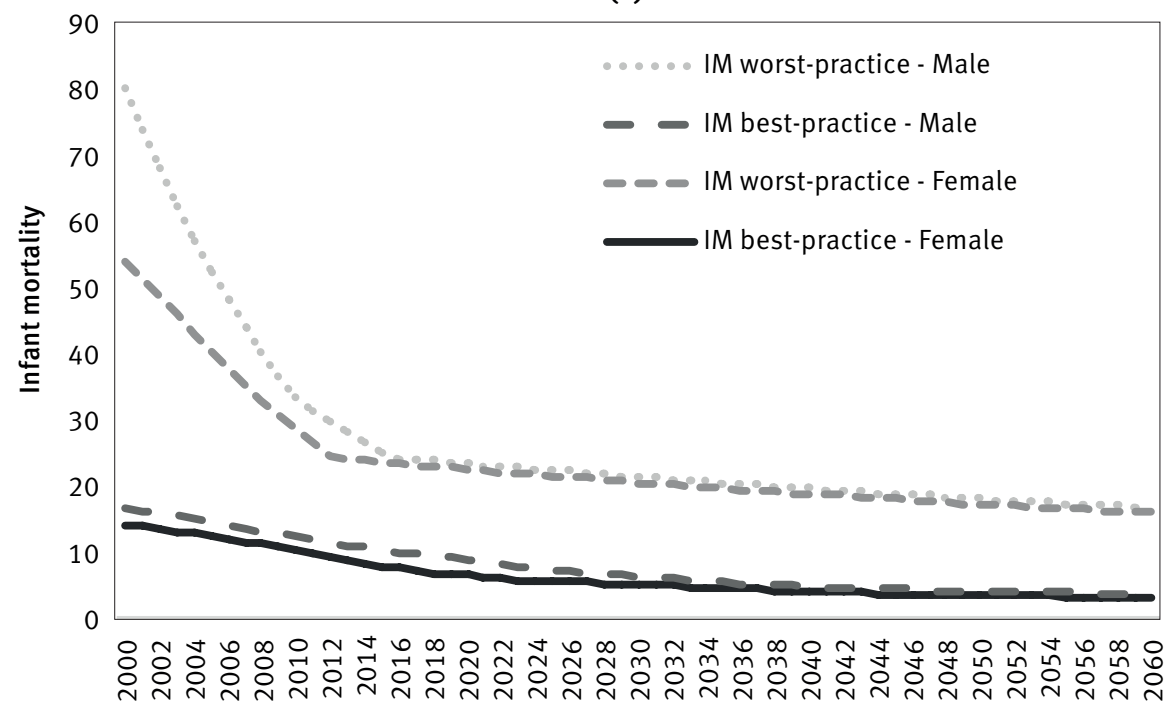

(b)

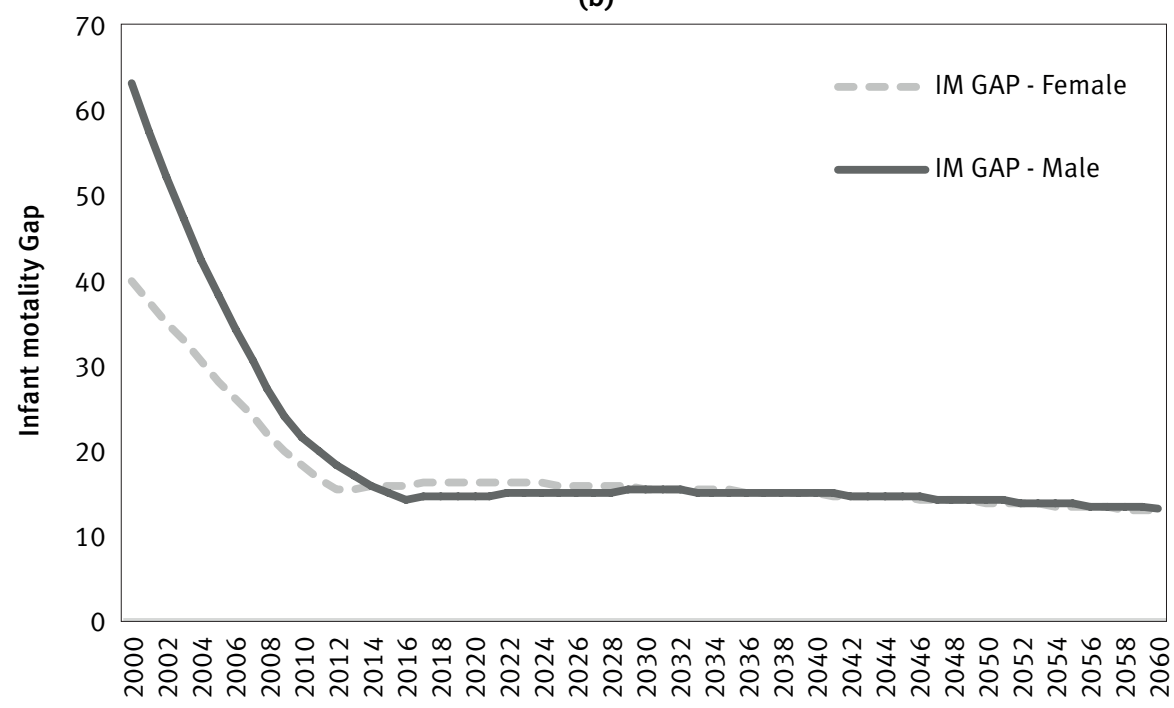

Source: Author's calculations based on the Brazilian Institute of Geography and Statistics (https://www.ibge.gov.br/).

\section{Discussions}

Our results revealed clear discrepancies among Brazilian Federation Units concerning the timing of balancing of their life tables. While the Federal District and all the states from the South and Southeast regions were the first to achieve balancing, most of the 
states from the Midwest and Northeast and especially the states from the North have not experienced it yet. At national level, females were the first to overcome the life table paradox in 2016, while for the males this happened in 2018. However, when analyzing the Federation Units, the median years of balancing for females and males are expected to be 2020 and 2022, respectively. Moreover, for both males and females, we also observed negative and statistically significant correlations between life expectancy at birth and the $I M$ at the timing of the balancing.

Canudas-Romo and Becker (2011), using data from the Human Mortality Database HMD (https://www.mortality.org/), pointed out that, for industrialized nations, the first observed balanced life tables were those from Iceland (in 1957 for females, and in 1967 for males), and the last ones were those from Russia (in 2000, for females) and from Bulgaria (in 2003, for males). In addition, for all analyzed countries (but Slovenia) the balancing occurred for females first. According to the authors, in Slovenia, the life table paradox was overcome, for both males and females, in 1983. However, at this point it is worth noting that at the HMD the historical series of life tables for Slovenia starts in 1983, and that, for males, even though the 1983 life table was balanced, the 1984 and 1985 tables were not. Therefore, due to lack of information for the years prior to 1983 and the fact that fluctuations in life expectancy were observed before the Slovenian male life tables became effectively balanced, conclusions about Slovenia (and other nations with short historical series, such as (hile) should be taken with caution, since the years before the starting point of the series could also be part of a fluctuation process that culminated in a balanced table.

Dubey, Ram and Ram (2015) investigated the timing of crossing between life $e_{0}$ and $e_{5}$ and between $e_{0}$ and $e_{1}$ for India (a country marked by social inequalities) and some selected states. They found that, until 2009, for all states in their sample in which both males and females had already experienced the crossing between life $e_{0}$ and $e_{5}$, it happened first for males.

In that regard, our results indicated that although Brazil and most of its Federation Units experienced (or are expected to experience) balancing for females before males, for six states (Roraima, Tocantins, Piauí, Paraíba, Alagoas and Bahia) from the North and Northeast, the poorest regions in Brazil, males are expected to experience balancing in their life tables before females. In Roraima, particularly, males are expected to overcome the life table paradox 11 years before females. However, irrespective of who (males or females) overcame or are expected to overcome the paradox first, females always presented (or are expected to present) higher levels of life expectancy at birth and lower levels of infant mortality at the timing of the crossing. This fact could be explained since females' life expectancy at age one reached higher levels than that for males, due to lower mortality levels after age one, which implies that females' infant mortality needed to reach a lower level than that for males so that the crossing between life expectancies at birth and at age one could happen (CANUDAS-ROMO; BECKER, 2011). Moreover, as explained by Moura et al. 
(2016), mortality differences between sex are the result of a set of factors such as biological and genetic differences, health behaviors, social behaviors and exposure to external causes of death (criminality and car accidents, for example) among others.

By the decomposition analysis, Canudas-Romo and Becker (2011, p.126) were able to classify the changes over time between $e_{0}$ and $e_{1}$ in three types: (1) a decline in both components (above and below age one over time); (2) fluctuations in both components over time, causing the fluctuation of the total change; and (3) a bell shape type. Moreover, in the whole period under investigation (1960s-2000s), their illustrative examples had the 'total change' and the 'below age one' component greater than zero, but, in some cases, their results also indicated values greater than zero for the 'above age one' component.

Our results differ from those of Canudas-Romo and Becker (2011) in two main aspects: For Brazil and all of its Federation Units, the 'above age one' component was (and is expected to be) negative; and for some states (Pernambuco, Rio Grande do Norte, Ceará and Alagoas), we expect to observe a decline in both components in such a way that the total change over time will go from a positive to a negative value, i.e., the above age one component will have a greater impact on the total change over time than the below age one component. However, even though we have observed, for these four Northeastern states, a process of reduction of difference between the life expectancy at birth and at age one over the final decades of the projected period, the total changes over time A + B are too low and, therefore, do not allow any conjecture about possible reversion of the balancing process in a long run.

In our final analysis, we discussed the relationship between best- and worst-practices in life expectancy at birth and in infant mortality, providing the magnitude of the inequalities in the main metrics under study. The results showed that the worst-practices were observed (and are expected to be observed) in the states of the North or Northeast regions and, on the other hand, the best-practices were observed (and are expected to be observed) in states from the South or Southeast or in the Federal District. Besides that, by analyzing the gaps, it was possible to observe a process of convergence and divergence between the worst- and best-practices, especially for male life expectancy at birth. For infant mortality, the major reductions in the gap happened from the 2000s to the early 2010 s, leading to a higher homogenization of IM in the country, as was also observed by França et al. (2017), but regional inequalities are still persistent and relevant.

Boing et al. (2020) noted that, from 1990 to 2010, Brazil made significant improvements in expanding and decentralizing health and sanitation services, in increasing the education level of its population and in implementing relevant social and pro-poor cash transference policies, which had important effects on health indicators such as life expectancy at birth and infant mortality, and on the reduction of regional inequalities. Nevertheless, Russo et al. (2019) indicated that despite improvements in the past decades, Brazil is still far from the IM level already achieved by the developed world. 
Boing et al. (2020) also observed that, since 2015, the country has experienced low economic growth and cuts in public investments, which could slow down (or compromise) the progresses that have been made. Moreover, the COVID-19 pandemic has been imposing economic retraction, aggravating the current situation, and is also expected to have a negative impact on life expectancy. In this regard, Castro et al. (2021), based on the death counts by COVID-19 in Brazil in 2020, estimated that life expectancy at birth has declined 1.98 years for males, and 1.82 years for females. Moreover, the authors also estimated the decline in life expectancy in an alternative scenario, assuming that $90 \%$ of the deaths by Severe Acute Respiratory Infection without a confirmed diagnosis were caused by COVID-19. Under this hypothesis, the declines were of 2.56 years for males, and 2.37 years for females. It is also worth mentioning that the official count of deaths by COVID-19 from January to April 2021 has already outnumbered the total amount registered in 2020 (CONSELHO NACIONAL DE SECRETÁRIOS DE SAÚDE, 2021), which will probably lead to even more significant negative impacts on life expectancy.

According to França et al. (2017, p.53) the main causes of child mortality ( 5 years old) in 1990 and 2015 were (the rank of each cause in 1990 and 2015, respectively, is also presented): prematurity $\left(1^{\text {st }}, 1^{\text {st }}\right)$, congenital anomalies $\left(5^{\text {th }}, 2^{\text {nd }}\right)$, asphyxia and trauma at birth $\left(4^{\text {th }}, 3^{\text {rd }}\right)$, septicaemia and other neonatal infection $\left(6^{\text {th }}, 4^{\text {th }}\right)$, lower respiratory infections $\left(3^{\text {rd }}, 5^{\text {th }}\right)$, other neonatal disorders $\left(9^{\text {th }}, 6^{\text {th }}\right)$, diarrheal diseases $\left(2^{\text {nd }}, 7^{\text {th }}\right)$, meningitis $\left(8^{\text {th }}\right.$, $8^{\text {th }}$ ) and malnutrition $\left(7^{\text {th }}, 9^{\text {th }}\right)$. In this respect, França et al. (2017), Kale et al. (2019) and Tejada et al. (2019) indicated that most of those deaths could be prevented by simple and timely health measures. Additionally, Kale et al. (2019) highlighted that when child and infant mortalities decrease, most of child deaths become concentrated at the neonatal period (0-27 days). The authors also pointed out that in $2015,55 \%$ of all deaths up to the fifth year happened at the neonatal period.

Lansky et al. (2014) went further indicating that early neonatal mortality (0-6 days), especially at the first 24 hours, is the main component of IM.Which, for the authors, shows the importance of good health care during the pregnancy and delivery. In this context, Leal et al. (2020) argued that prenatal care is almost universal for women using the Brazilian Unified Health System (SUS), but if a minimum set of exams and other healthcare procedures were to be included in the analysis, an adequate prenatal care is only offered for a quarter of the women using the SUS, showing that the quality of the services provided is still deficient. It was also found that, compared to the rest of the country, the North and the Northeast regions present a higher frequency of pregnancy among adolescents and women with low economic and educational levels. Additionally, in the North, "the proportion of women with no prenatal care was the same for groups of women, with and without obstetric complications" (LEAL et al., 2020, p.9). For the authors, this result could be partially explained by geographical barriers in accessing health centers and the absence of qualified professionals.

Tomasi et al. (2017) developed an indicator of prenatal quality, based on which they found that only $15 \%$ of women received an adequate prenatal care, with the worst services 
provided to younger females, from low-income families, living in small municipalities (and with low Human Development Index) from the North and Midwest regions.

Additionally, the convergence/divergence process discussed plays an important role in the debate of epidemiological transition (VALLIN; MESLÉ, 2004; MESLÉ; VALLIN, 2017). In this sense, Borges (2017, p. 3) states that "the epidemiological transition in Brazil has not followed the model experienced by most developed countries". Alvarez, Aburto and Canudas-Romo (2020) argue that the epidemiological transition theory was conceived in the developed world and, for this reason, it might fail to explain mortality and health trends in the developing world. Moreover, the authors indicated that Brazil is also heavily affected by amenable diseases and has high rates of violence and homicide, especially among men, which is one of the factors preventing the country from achieving the mortality regime of developed nations.

\section{Limitations and research agenda}

For a better interpretation of the results, and in order to develop or strengthen a research agenda, it is fundamental to clearly identify the main limitations of an academic investigation and to propose future paths of study (SOUZA, 2020). In this regard, we understand that the first issue that must be addressed in this subsection is the use of estimated and projected life tables. Although we have used official life tables provided by the Brazilian Institute of Geography and Statistics, which is undoubtedly a natural choice when studying aspects related to mortality and life expectancy in Brazil, we must be aware that the value of some metrics such as life expectancy at birth and infant mortality are influenced by the methods/hypotheses used to construct the life table (MISSOV; NÉMETH; DANKO, 2016; SHOLNIKIV, 2017). Moreover, as pointed by Wolff, Chong and Auffhammer (2011), social metrics released in a given year must be viewed as an inexact value, which could be revised due to data or methodological updating, for example.

Along these lines, although population projections are an important demographic tool and a fundamental one for public planning (OLIVEIRA; SILVA; OLIVEIRA, 2019), unforeseen events, particularly the current COVID-19 pandemic, will surely have a negative impact, at least in the short term, in life-expectancy and might affect regions (CASTRO et al., 2021) and subpopulations in different levels. The AIDS epidemic, for example, caused expressive losses in life-expectancy in Africa during the 1990s (SOUZA; RÊGO, 2018).

Even without the pandemic, there is already evidence of differences in health indicators among Brazilian subpopulations. Hone et al. (2017), for example, stated that black and mixed (pardo) races had higher mortality rates from homicides and external causes, are more affected by infectious diseases and had lower life expectancy. Chiavegatto Filho, Beltrán-Sánchez and Kawachi (2014) also pointed out that black and mixed races had lower educational and income levels when compared to whites, and live in more violent communities, which have a negative impact in perpetuating racial inequalities in Brazil. In 
this regard, Caldas et al. (2017) complemented that the recent reductions in infant mortality in Brazil had less expressive effects for the indigenous subpopulation.

Moreover, the recent episodes of immigration (and refugees) in the 2010s, especially from Haiti and Venezuela (OLIVEIRA; SILVA; OLIVEIRA, 2019), and the fact that immigration disproportionally affects Brazilian regions, also demand attention. Unlike immigrants that move to other countries seeking for better job opportunities, for example, refugees had to leave their nations as a matter of survival (MOKDAD et al., 2016), and because of that, they may arrive in the new country in a situation of social vulnerability. In a recent study, Simeoni, Frova and De Curtis (2019) found high disparities between infant mortality among Italian residents and immigrants, especially for children from mothers coming from Africa.

Altogether, those facts call for the monitoring of consequences of the COVID-19 pandemic (and of the social isolation) in health metrics, especially in life expectancy; besides quality data and investigations that address the case of Brazilian subpopulations.

A final point to be highlighted is the difference between period and cohort metrics, particularly regarding life expectancy. The period life expectancy expresses the average length of life of a synthetic cohort, assuming that the age-specific death rates will remain constant over time; while the cohort life expectancy expresses the average length of life of a real cohort of people born at the same calendar year (GOLDSTEIN; WACHTER, 2006; LUY et al., 2019; MODIG; RAU; AHLBOM, 2020). Therefore, even though period life expectancy at birth reflects the mortality conditions of a population in a certain period (LUY et al., 2019), which is indisputably a very important health indicator, it does not reflect the average number of years that a newborn child will be expected to live in a real population. Additionally, period life expectancy may be affected by tempo, heterogeneity and cohort effects (LUY et al., 2019; MODIG; RAU; AHLBOM, 2020).

In this regard, Canudas-Romo and Becker (2011) already observed that, since mortality rates typically reduce over time, it is most certain that the timing of balancing of the life tables should be observed earlier if cohort tables were used. This conjecture emphasizes the importance of the construction of official cohort life tables for Brazil and its Federation Units and subpopulations.

\section{Conclusion}

Inspired by Canudas-Romo and Becker (2011), this article investigated the timing (and health metrics at the time) in which Brazil and its Federation Units overcame (or are expected to overcome) the life table paradox, also exploring regional and sex health inequalities. From a public planning perspective, we understand that achieving a balance in the life tables is a goal to be pursued, especially because, roughly speaking, having an imbalanced table means that life expectancy at birth is still strongly influenced by high levels of infant mortality. Therefore, knowing the expected time and health metrics at that 
moment, public planners could properly define, for each sex and region, strategies to accelerate the balancing process and revert unequal scenarios.

\section{References}

ALVAREZ, J.-A.; ABURTO, J. M.; CANUDAS-ROMO, V. Latin America convergence and divergence towards the mortality profiles of developed countries. Population Studies, v. 74, n. 1, p. 75-92, 2020.

BOCCOLINI, C. S.; SOUZA JUNIOR, P. R. B. Inequities in healthcare utilization: results of Brazil National Health Survey 2013. International Journal for Equity in Health, v. 15, p. 1-8, 2016.

BOING, A. F. et al. Narrowing geographic inequality in life expectancy in Brazil: a multilevel analysis between 1991 and 2010. Public Health, v. 180, p. 102-108, 2020.

BORGES, G. M. Health transition in Brazil: regional variations and divergence/convergence in mortality. Cadernos de Saúde Pública, v. 33, n. 8, e00080316, 2017.

CALDAS, A. D. R. et al. Infant mortality according to color and race based on the 2010 Population Census and National Health Information System in Brazil. Cadernos de Saúde Pública, v. 33, n. 7, .e00046516, 2017.

CANUDAS-ROMO, V.; BECKER, S. The crossover between life expectancies at birth and at age one: the imbalance in the life table. Demographic Research, v. 24, p. 113-144, 2011.

CASTRO, M. C. et al. Reduction in the 2020 life expectancy in Brazil after COVID-19. medRxiv, 2021. Available at: https://doi.org/10.1101/2021.04.06.21255013. Accessed on: 12 Apr. 2021.

CHIAVEGATTO FILHO, A. D. P.; BELTRÁN-SÁNCHEZ, H.; KAWACHI, I. Racial disparities in life expectancy in Brazil: challenges from a multiracial society. American Journal of Public Health, v. 104, n. 11, p. 2156-2162, 2014.

CONSELHO NACIONAL DE SECRETÁRIOS DE SAÚDE. Painel CONASS COVID-19. 2021. Available at: https://www.conass.org.br/painelconasscovid19/. Accessed on: 1 May 2021.

DUBEY, M.; RAM, U.; RAM, F. Threshold levels of infant and under-five mortality for crossover between life expectancies at ages zero, one and five in India: a decomposition analysis. PLoS ONE, v. 10, n. 12, e0143764, 2015.

FRANÇA, E. B. et al. Leading causes of child mortality in Brazil in 1990 and 2015: estimates from the Global Burden of Disease study. Revista Brasileira de Epidemiologia, v. 20, n. 1, p. 46-60, 2017.

GISBERT, F. J. G. Distributionally adjusted life expectancy as a life table function. Demographic Research, v. 43, p. 365-400, 2020.

GOLDSTEIN, J. R.; WACHTER, K. W. Relationships between period and cohort life expectancy: gaps and lags. Population Studies, v. 60, n. 3, p. 257-269, 2006.

HONE, T. et al. Association between expansion of primary healthcare and racial inequalities in mortality amenable to primary care in Brazil: a national longitudinal analysis. PLoS Medicine, v. 14, n. 5, e1002306, 2017.

IBGE - Instituto Brasileiro de Geografia e Estatística. Projeções da população por sexo e idade Brasil: 2000-2060 e unidades da federação - 2000-2030. Rio de Janeiro: IBGE, 2013a. Available at: https://www.ibge.gov.br/estatisticas/sociais/populacao/9109-projecao-da-populacao. html?edicao=9116\&t=resultados. Accessed on: 16 Jun. 2020. 
IBGE - Instituto Brasileiro de Geografia e Estatística. Projeções da população: Brasil e unidades da federação. Rio de Janeiro: IBGE, 2013b.

IBGE - Instituto Brasileiro de Geografia e Estatística. Tábuas abreviadas de mortalidade por sexo e idade: Brasil, grandes regiões e unidades da federação: 2010. Rio de Janeiro: IBGE, 2013C.

IBGE - Instituto Brasileiro de Geografia e Estatística. Projeções da população do Brasil e unidades da federação por sexo e idade: 2010-2060. Rio de Janeiro: IBGE, 2018a. Available at: https://www. ibge.gov.br/estatisticas/sociais/populacao/9109-projecao-da-populacao.html?=\&t=resultados. Accessed on: 16 Jun 2020.

IBGE - Instituto Brasileiro de Geografia e Estatística. Projeções da população: Brasil e unidades da federação: revisão 2018. Rio de Janeiro: IBGE, 2018b.

KALE, P. L. et al. Life-threating conditions of birth: an analysis of causes of death and survival estimated for under-five children in live birth cohorts. Cadernos de Saúde Pública, v. 35, n. 7, e00186418, 2019.

LANSKY, S. et al. Birth in Brazil survey: neonatal mortality, pregnancy and childbirth quality care. Cadernos de Saúde Pública, v. 30, sup., p. S1-S15, 2014.

LEAL, M. C. et al. Prenatal care in the Brazilian public health services. Revista de Saúde Pública, v. 54, n. 8, p. 1-12, 2020.

LUY, M. et al. Life expectancy: frequently used, but hardly understood. Gerontology, v. 66, p. 95-104, 2019.

MATHERS, C. D. et al. Causes of international increases in older age life expectancy. Lancet, v. 385, p. 540-548, 2015.

MESLÉ, F.; VALLIN, J. The end of East-West divergence in European life expectancies? An introduction to the special issue. European Journal of Population, v. 33, p. 615-627, 2017.

MISSOV, T. I.; NÉMETH, L.; DANKO, M. J. How much can we trust life tables? Sensitivity of mortality measures to right-censuring treatment. Palgrave Communications, v. 2, article 15049, 2016.

MODIG, K.; RAU, R.; AHLBOM, A. Life expectancy: what does it measure? BMJ Open, v. 10, e035932, 2020.

MOKDAD, A. H. et al. Health in times of uncertainty in the eastern Mediterranean Region, 19902013: a systematic analysis for the global burden of disease study 2013. Lancet Global Health, v. 4, n. 10, 2016.

MOURA, E. C. et al. Mortality in Brazil according to gender perspective, years 2000 and 2010. Revista Brasileira de Epidemiologia, v. 19, n. 2, p. 326-338, 2016.

OEPPEN, J.; VAUPEL, J. W. Broken limits to life expectancy. Science, v. 296, n. 5570, p.1029-1031, 2002.

OLIVEIRA, H. N.; SILVA, C. A. M.; OLIVEIRA, A. T. R. Imigração internacional: uma alternativa para os impactos das mudanças demográficas no Brasil? Revista Brasileira de Estudos de População, v. 36, p. 1-31, e0076, 2019.

ROWLAND, D. T. Demographic methods and concepts. Oxford: Oxford University Press, 2003.

RUSSO, L. X. et al. Primary care physicians and infant mortality: evidence from Brazil. PLoS ONE, v. 14, n. 5, e0217614, 2019.

SHKOLNIKOV, V. Methods protocols for the human life-table database. Version 2. 2017. Available at: https://www.lifetable.de/methodology.pdf. Accessed on: 15 Apr. 2021. 
SIMEONI, S.; FROVA, L.; DE CURTIS, M. Inequalities in infant mortality in Italy. Italian Journal of Pediatrics, v. 45, n. 11, p. 1-7, 2019.

SMITHS, J.; MONDEN, C. Length of life inequality around the globe. Social Science \& Medicine, v. 68, p. 1114-1123, 2009.

SOUZA, F. C. Relationships between best-practice and greatest possible life expectancies. European Journal of Ageing, v. 17, p. 331-339, 2020.

SOUZA, F. C.; RÊGO, L. C. Life expectancy and health life expectancy changes between 2000 and 2015: an analysis of 183 World Health Organization member states. Journal of Public Health: From Theory to Practice, v. 26, n. 3, p. 261-269, 2018.

TEJADA, C. A. et al. Economic crises, child mortality and the protective role of public health expenditure. Ciências \& Saúde Coletiva, v. 24, n. 12, p. 4395-4404, 2019.

TOMASI, E. et al. Quality of prenatal services in primary healthcare in Brazil: indicators and social inequalities. Cadernos de Saúde Pública, v. 33, n. 3, e00195815, 2017.

VALLIN, J.; MESLÉ, F. Convergences and divergences in mortality; a new approach to health transition. Demographic Research, Special Collection 2, p. 11-44, 2004.

VAUPEL, J. W. Biodemography of human ageing. Nature, v. 464, p. 536-542, 2010.

WOLFF, H.; CHONG, H.; AUFFHAMMER, M. Classification, detection and consequences of data error: evidence from the Human Development Index. The Economic Journal, v. 121, n. 553, p. 843-870, 2011.

\section{About the author}

Filipe Costa de Souza holds a PhD in Economics from Universidade Federal de Pernambuco (UFPE) and he is currently a professor at the Departamento de Ciências Contábeis e Atuariais, also at UFPE.

\section{Contact address}

Universidade Federal de Pernambuco, Centro de Ciências Sociais Aplicadas, Departamento de Ciências Contábeis e Atuariais

Avenida dos Funcionários, s/n, Cidade Universitária

50670-901 - Recife-PE, Brazil

\section{Resumo}

O paradoxo da tábua de sobrevivência: o Brasil já o superou?

Idealmente, a expectativa de vida deveria ser uma função decrescente da idade. Quando tal fato não é observado, a situação é conhecida como o paradoxo da tábua de mortalidade. Este artigo investigou o momento (e métricas de saúde neste momento) em que o Brasil e suas unidades da federação (UF) superaram (ou são esperados superar) este paradoxo. Os dados foram obtidos do Instituto Brasileiro de Geografia e Estatística e continham 3.416 tábuas de mortalidade abreviadas e específicas por sexo, de 2000 até 2060. No nível nacional, mulheres e homens superaram o paradoxo em 2016 e 2018, respectivamente. Contudo, quando foram 
examinadas as UFs separadamente, grande heterogeneidade foi observada. Pela análise de decomposição da mudança no tempo da diferença entre a expectativa de vida ao nascer e na idade de um ano, observamos que o Brasil e a maioria de suas UFs esperam ter ambas as mudanças decrescentes ao longo do tempo e a mudança total é esperada ser decrescente e maior do que zero. Entretanto, para alguns estados do Nordeste, a mudança total é esperada passar de um valor positivo para um negativo; e para dois estados do Norte a mudança total esperada não deve ser nem crescente nem decrescente. Em uma perspectiva de planejamento público, entendemos que alcançar o balanceamento das tábuas de mortalidade é um objetivo a ser perseguido, especialmente porque ter uma tábua desbalanceada significa que a expectativa de vida ao nascer ainda é fortemente influenciada pelos altos níveis de mortalidade infantil. Assim, este conhecimento pode ajudar planejadores a definirem estratégias apropriadas para acelerar o processo de balanceamento e reverter cenários de desigualdade.

Palavras-chave: Tábua de sobrevivência. Expectativa de vida. Mortalidade infantil. Desigualdades em saúde. Desigualdades regionais. Decomposição.

\section{Resumen}

La paradoja de la tabla de vida: ¿Brasil ya a la superó?

Idealmente, la esperanza de vida debería ser una función decreciente de la edad. Cuando esto no sucede, se conoce al hecho como la paradoja de la tabla de mortalidad. Este artículo investigó el momento -y las medidas de salud en ese momento- en que Brasil y sus unidades de la federación UF) superaron -o se espera que superen- esta paradoja. Los datos fueron tomados del Instituto Brasileño de Geografía y Estadística (IBGE) y contenían 3416 tablas de vida abreviadas oficiales y específicas por sexo, desde 2000 hasta 2060, para Brasil y sus 27 UF. A el ámbito nacional, mujeres y hombres habían superado la paradoja en 2016 y 2018 , respectivamente. Sin embargo, cuando las UF se examinaron por separado, se observó una gran heterogeneidad. Mediante el análisis de descomposición del cambio a lo largo del tiempo en la diferencia entre la esperanza de vida al nacer y al primer año de edad, encontramos que se espera que Brasil y la mayoría de sus UF presenten cambios que disminuyan con el tiempo y se espera que el cambio total disminuya y sea mayor que cero. No obstante, para algunos estados del noreste, se espera que el cambio total se oriente desde un valor positivo hacia uno negativo, así como para dos estados del norte el cambio total esperado no debería aumentar ni disminuir. En una perspectiva de planificación pública, entendemos que lograr una tabla de mortalidad equilibrada es un objetivo a perseguir, especialmente porque tener una tabla desequilibrada significa que la esperanza de vida al nacer sigue estando fuertemente influida por los altos niveles de mortalidad infantil. Por lo tanto, este conocimiento puede ayudar a los planificadores a definir estrategias adecuadas para acelerar el proceso de equilibrio y revertir los escenarios de desigualdad.

Palabras clave: Tabla de vida. Esperanza de vida. Mortalidad infantil. Desigualdades en salud. Desigualdades regionales. Descomposición. 


\section{Appendix}

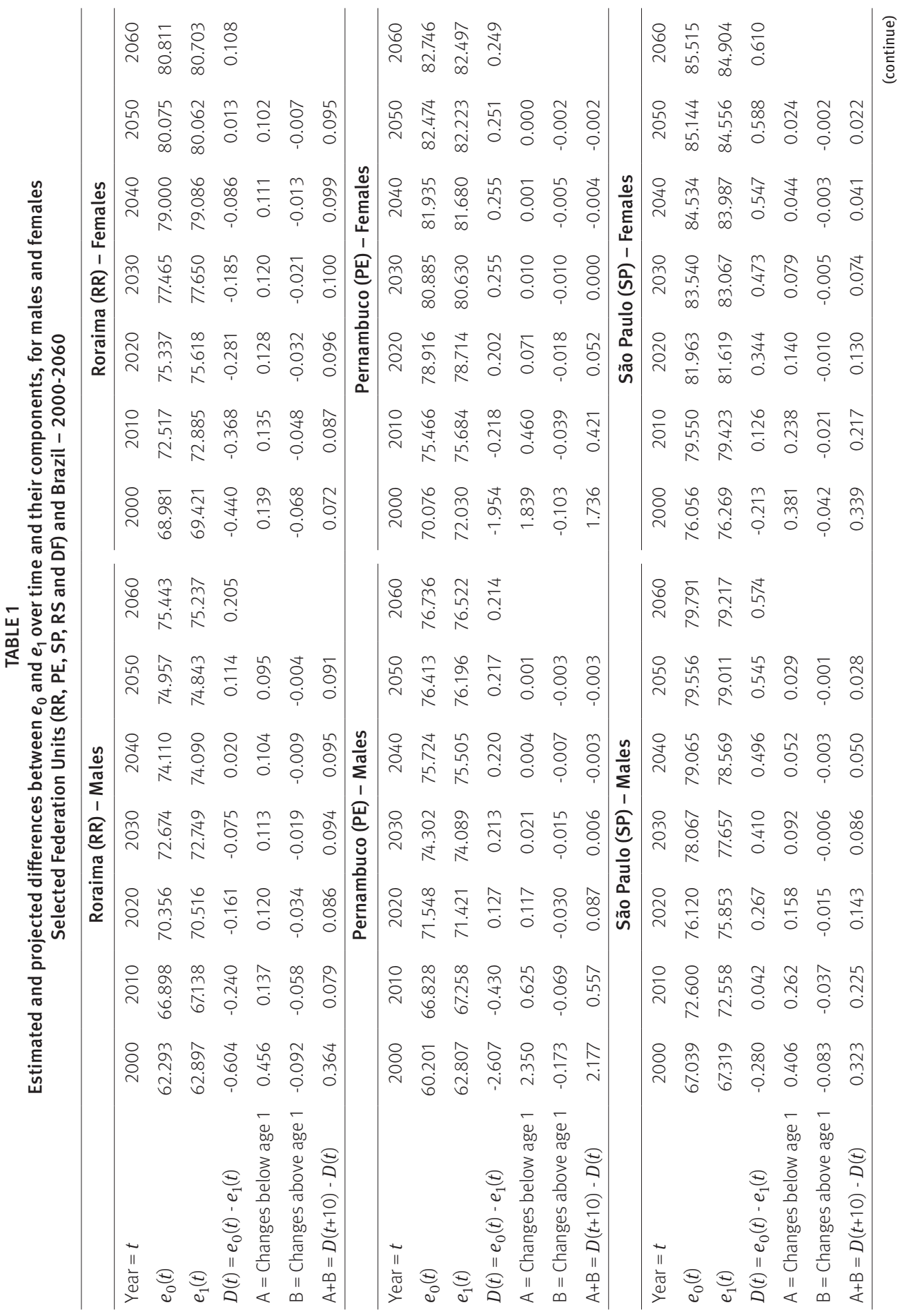




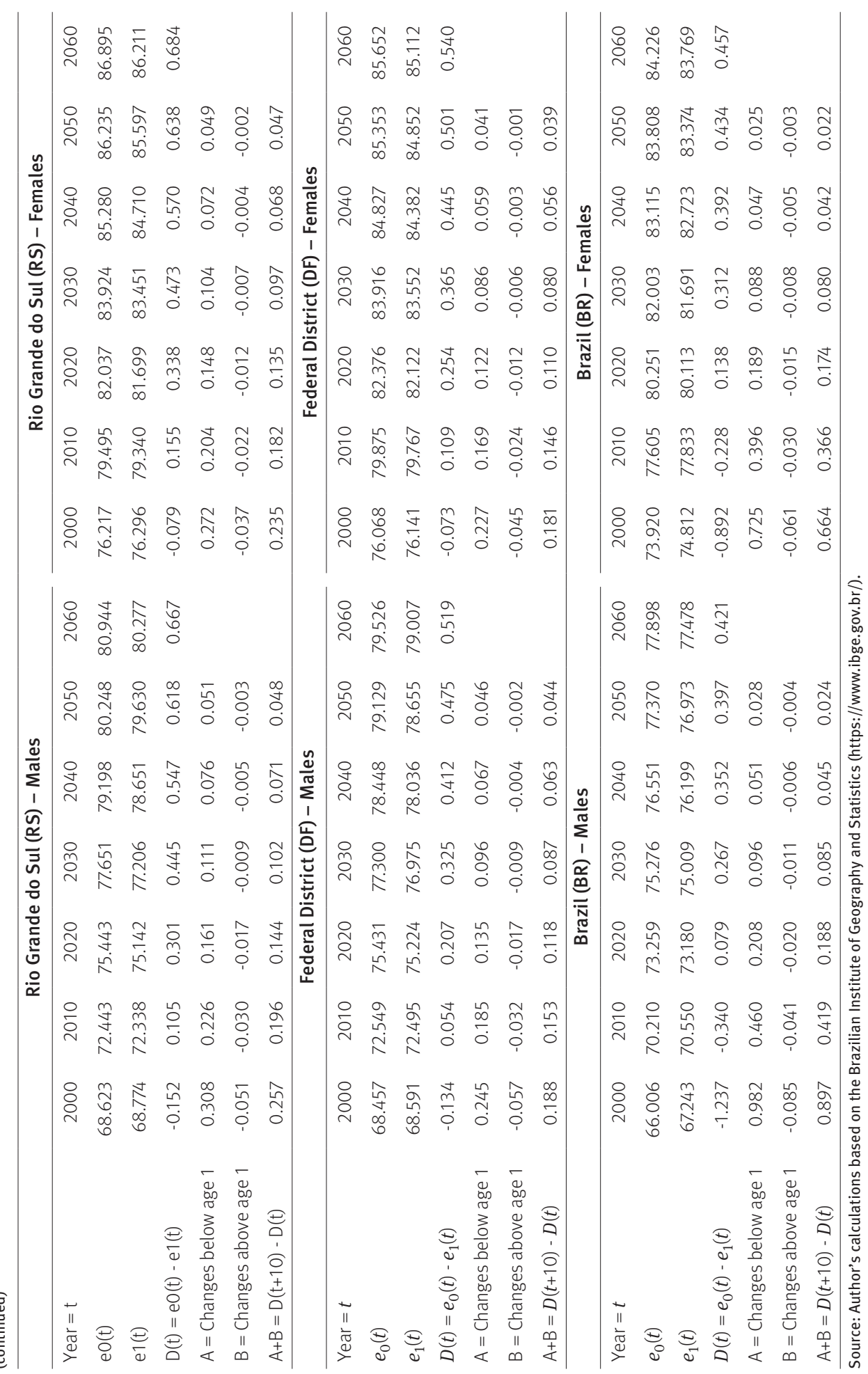

